\title{
Extent and Evaluation of Protection in Developing Countries
}

\author{
J. KOL \\ Faculty of Economics, Erasmus Centre for Economic Integration Studies, Erasmus University, \\ Rotterdam, The Netherlands
}

Key words: protection, trade policies, trade liberalization, developing countries, preferential treatment, resource allocation

\section{Abstract}

Tariff protection and nontariff barriers are higher in developing countries than in industrial nations. The tendency of protection to decline with a higher level of development can be explained by the role of import taxes in government revenue, by export pessimism, and by differential treatment of developing countries under GATT.

Protection against imports is a burden on the export sector. Trade liberalization has important effects on economic growth and factor productivity. Recent programs of trade liberalization are implemented together with complementary macroeconomic policies to enhance the possibility of sustaining trade policy reforms to be sustained.

Theoretical and empirical evidence points to a phase of industrialization as indispensable for economic development in most countries, the efficiency of which is closely connected with the design of trade policies.

The review of trade policies in developing countries in Section 1 includes the extent of tariff protection and of nontariff barriers (NTBs), the escalation of tariffs, and the connection between the level of protection and the stage of development.

Section 2 offers an explanation for the extent of protection in developing countries. Explaining factors include the various types of development design, the role of government revenue, and that of balance of payments difficulties, and the preferential treatment of developing countries in world trade.

The effects of protection policies are reviewed in Section 3. It includes a general introduction on the efficiency of resource allocation as influenced by protectionist measures. The costs of protection are further analyzed using the concepts of effective protection, of domestic resource costs, and that of true protection. Finally, an overview is given of the experience of developing countries with design and implementation of policies for trade liberalization.

A summary of the main findings concludes the article in Section 4. 


\section{The structure of protection in developing countries}

\subsection{Extent}

A recent and comprehensive survey of trade control measures in developing countries is given in UNCTAD (1990). The survey covers 62 developing countries, and in terms of measures it includes, tariffs, other charges, customs receipts, and nontariff measures (NTMs). ${ }^{1}$ The main results are represented in Table 1.

For all products the 1985 trade-weighted average tariff is 21.3 percent, with similar figures for the two broad subcategories: primary products and manufactures. Total charges including next to tariffs, customs surcharges, stamp taxes, and other fiscal charges, are on average one third higher than the average tariff. With respect to the nontariff measures, the unweighted frequency average for all products is $\mathbf{4 1 . 6}$

Table 1. Tariffs and nontariff barriers in developing countries, 1985.

\begin{tabular}{|c|c|c|c|c|c|}
\hline \multirow[b]{2}{*}{ Product Group } & \multirow[b]{2}{*}{ SITC } & \multicolumn{2}{|c|}{$\begin{array}{l}\text { Tariff Barriers } \\
\text { Percentages }^{\text {a }}\end{array}$} & \multicolumn{2}{|c|}{$\begin{array}{l}\text { Nontariff Barriers } \\
\text { Frequencies }^{\mathrm{a}}\end{array}$} \\
\hline & & $\begin{array}{c}\text { Tariffs } \\
(\%)\end{array}$ & $\begin{array}{c}\text { Total } \\
\text { Charges } \\
(\%)\end{array}$ & $\begin{array}{c}\text { Quantitative } \\
\text { Restrictions } \\
\text { (\%) }\end{array}$ & $\begin{array}{c}\text { All } \\
\text { Measures } \\
(\%)\end{array}$ \\
\hline All Products & $0-8$ & 21.3 & 28.8 & 41.6 & 62.3 \\
\hline Primary Products & $0-4,67,68$ & 19.2 & 26.4 & 43.3 & 63.8 \\
\hline Manufactures & $5-8$, less 67,68 & 22.3 & 30.0 & 40.1 & 61.0 \\
\hline Food Products & $0,1,22,4$ & 25.6 & 33.6 & 49.5 & 67.4 \\
\hline Vegetables and fruit & 05 & 35.3 & 45.2 & 53.1 & 69.1 \\
\hline Coffee, tea, cocoa, spices & 07 & 31.7 & 41.7 & 44.8 & 65.0 \\
\hline Agricultural raw materials & 2 less $22,27,28$ & 16.2 & 23.7 & 35.3 & 58.4 \\
\hline Mineral fuels & 3 & 15.3 & 21.9 & 37.1 & 61.2 \\
\hline Ores and metals & $27,28,67,68$ & 15.2 & 22.0 & 34.1 & 57.9 \\
\hline Chemical products & 5 & 16.9 & 23.6 & 39.2 & 61.1 \\
\hline Fertilizers & 56 & 4.7 & 10.1 & 43.8 & 66.8 \\
\hline Diverse manufactures & 6,8 less 67,68 & 30.1 & 39.2 & 42.2 & 61.8 \\
\hline Cork and wood products & 63 & 31.2 & 42.1 & 38.2 & 61.2 \\
\hline Newsprint & 6411 & 12.2 & 18.7 & 41.6 & 61.8 \\
\hline Textiles & 6511 & 34.5 & 44.7 & 43.9 & 65.2 \\
\hline Furniture & 82 & 43.9 & 54.4 & 54.1 & 67.0 \\
\hline Clothing & 84 & 47.1 & 60.4 & 56.6 & 71.0 \\
\hline Footwear & 85 & 39.3 & 50.8 & 50.4 & 66.2 \\
\hline Scientific instruments & 87 & 14.8 & 21.1 & 32.6 & 56.3 \\
\hline Machinery and equipment & 7 & 20.6 & 28.0 & 38.7 & 60.2 \\
\hline Color TV receivers & 7611 & 41.4 & 51.0 & 52.8 & 70.5 \\
\hline Passenger cars & 7810 & 51.9 & 66.8 & 65.7 & 80.0 \\
\hline Parts of aircraft & 7929 & 9.0 & 14.5 & 32.0 & 57.6 \\
\hline
\end{tabular}

Source: UNCTAD (1990).

asee Appendix 1 for country coverage and definitions of trade barriers. Tariffs and total charges represent trade-weighted averages. Nontariff barriers are non-weighted frequency averages. 
percent for quantitative restrictions alone and 62.3 percent for all measures. As in the case of tariffs, the average NTM-coverage for primary products and for manufactures is close to the average for all products.

At a lower level of aggregation, however, there are marked differences in protection among product groups. Within primary products, tariffs and total charges are much lower for raw materials and mining products than for food products; to a lesser extent the same holds for NTM-coverage for these product groups. Within manufactures, tariff protection on clothing, footwear, furniture, and textiles is particularly high, but it is relatively low on fertilizers, aircraft parts, and scientific instruments.

In more general terms, UNCTAD (1990) concludes, that both the level and structure of import taxation and NTMs in developing countries present a barrier to the expansion of intradeveloping countries' trade, by penalizing products that, due to resource endowment (agro-based consumer goods) and relative factor endowment (manufactured labor-intensive goods), have gained these countries' highest comparative advantages on the world market.

Regarding the nature of NTMs in developing countries, UNCTAD (1990) found that these measures are on the whole nondiscriminatory. On the basis of a detailed investigation involving $\mathbf{5 0}$ developing economies, it was found that legislation on NTMs very rarely specifies individual partner countries and that the NTMs most commonly used are of a general nature and are not pointed at individual suppliers. The NTMs involved are licensing, advanced import deposits, and central bank authorizations. ${ }^{2}$

Since tariffs and NTMs both have the effect of restricting imports, it could be expected that the two types of measures are used as alternatives. On the other hand, especially in developing countries, tariffs serve also as a source of government revenue, whereas NTMs are meant to control the amount of imports, such as when there is a scarcity of foreign exchange. These different purposes may require that both types of measures be used in combination. Erzan et al. (1989) have investigated this aspect in particular and conclude that tariffs for products where NTMs are also applied are on average 45 percent higher than those for products without NTMs. This leads to the conclusion that tariffs and NTMs are being used in combination rather than as alternatives. This finding is confirmed across sectors, most markedly for iron, steel, other metals, and machinery, where tariff on products with NTMs were 70 to 80 percent above the tariffs for the same type of goods not covered by NTMs. ${ }^{3}$

\subsection{Escalation}

Average tariffs for primary products and for manufactures do not deviate much according to the figures in Table 1. At a more detailed level, however, tariffs have a clear tendency to increase with the stage of processing. This escalation of tariffs has been investigated in detail for the structure of protection in developing countries by Laird and Yeats (1990). Some of the results are presented in Table 2 and suggest a high degree of tariff escalation in developing countries, especially for 
Table 2. Escalation of tariffs in developing countries.

\begin{tabular}{lcccrr}
\hline & \multicolumn{5}{c}{ Tariffs } \\
\cline { 2 - 6 } Processing Chain & Leather & Wood & Wool & Cotton & Iron \\
\hline Raw Materials & 1.5 & 2.5 & 4.0 & 1.0 & 0.1 \\
Semimanufactures & 15.9 & 6.4 & 17.8 & 22.3 & 5.9 \\
Finished Products & 46.2 & 42.1 & 27.6 & 30.9 & 24.2 \\
\hline
\end{tabular}

Source: Laird and Yeats (1990).

production chains in which these countries have a comparative advantage. However, in countries with no domestic production of the raw material concerned, escalation of tariffs in the particular product chain is usually not found.

Laird and Yeats (1990) simulate the effects of a preferential removal of tariffs (and their escalation) among developing countries and conclude that there is a potential rise of intradeveloping country trade of 14 percent above existing trade levels for nonpetroleum products. ${ }^{4}$

With respect to escalation in protection, Finger and Laird (1987) comment that such protection would attract processing activities to a country if it were the only one imposing it; however, in actuality when many countries-both developed and developing-apply escalation, the effects will cancel each other. ${ }^{5}$ Furthermore, in the aggregate, escalation in protection becomes a burden on commodity-producing and on commodity-using sectors in all countries. As a consequence, the simultaneous reduction of protection in both developed and developing economies would be a positive sum game.

\subsection{Protection and the level of development}

The suggestion in the previous section is that developing countries can be taken as a homogeneous group when it comes to the application of trade policy measures. There are, however, marked differences among developing countries in this respect. This is apparent, for instance, in Table 3, where the developing countries are classified according to the level of GDP per capita. Customs receipts representing tariffs, other charges actually collected, and NTMs have a clear tendency to decrease with the level of development. In developing countries with a per capita income of less than $\$ 500$ (in 1987) customs receipts are 30 percent of the import value and NTMs are applied with a frequency of 66 percent; these values are, respectively, a factor 20 and 10 higher than for the developing countries with an income per capita of over $\$ 5000$. This latter group of developing countries applies trade policy measures to an extent comparable to those in the industrial countries. On average, customs receipts in developing countries are nine times as high as in industrial countries, and NTMs are four times higher.

Within the income per capita range $\$ 500$ to $\$ 1500$, Erzan et al. (1989) distinguished two separate groups of developing countries around an income per capita 
Table 3. Protection and the level of development.

\begin{tabular}{lccc}
\hline \multicolumn{1}{c}{ Country Group } & Number & $\begin{array}{c}\text { Customs Receipts } \\
\text { in Percentages } \\
\text { a }\end{array}$ & $\begin{array}{c}\text { Nontariff Measures } \\
\text { Frequencies in Percentages } \\
1987\end{array}$ \\
\hline $\begin{array}{l}\text { Developing countries } \\
\text { with GDP/capita }\end{array}$ & 62 & 14.8 & 60.9 \\
- below $\$ 500$ & 22 & 30.0 & 65.9 \\
$-\$ 500-\$ 1500$ & 25 & 18.7 & 58.7 \\
$-\$ 1500-\$ 5000$ & 9 & 8.9 & 35.6 \\
$-\$ 5000$ and more & 6 & 1.6 & 7.1 \\
& & 1.7 & 13.9 \\
\hline
\end{tabular}

Source: UNCTAD (1990).

${ }^{a}$ Customs receipts as a trade-weighted average in percentages of the value of imports. Nontariff measures are an unweighted average of frequencies expressed in percentages. Appendix 1 gives details on coverage of countries and trade measures.

of $\$ 1000$. It turned out that the less developed country group was somewhat less protective than the higher developed group both for tariff protection and NTMs. ${ }^{6}$

Notwithstanding these important differences in protection levels among the various groups of developing countries, it was concluded that the product pattern of protection (Table 1) was largely the same, both for tariffs and NTMs (Erzan et al. 1989).

Comparing the data in Tables 1 and 3 , it follows that customs receipts in developing countries amount to 14.8 percent of imports, which is only half of the calculated average rate for tariffs and other charges of 28.8 percent. This indicates that a substantial amount of the potential duty revenue is not collected (UNCTAD 1990).

\subsection{Variation among individual developing countries}

Recently the IMF (1992) has documented the current structure of trade regimes in developing countries. The 36 countries studied were classified according to four types of trade regimes: three countries were classified as having a system of tight control on trade, and eight countries as having significant control; of the 25 other countries, 16 were classified as relatively open and nine as open. ${ }^{7}$ From the details in Appendix 2 it can be seen that quantitative restrictions on trade are virtually absent in the nine open countries and very moderately applied in the 16 countries classified as relatively open. In the three countries with tight control, quantitative restrictions are applied to well over 50 percent of total imports. Regarding tariffs and other charges, the IMF (1992) observes that only in the nine open countries is this type of protection low, whereas in the 27 other countries it remains high. These data testify to the substantial variation in trade regimes among developing countries. 


\section{Explaining the level of protection}

\subsection{Development design}

The previous section found that protection in developing countries is considerably higher than in industrial countries. Usually (IMF 1992), the high level of protection in developing countries is connected with the adoption in the 1960 s by many of these countries of import substitution as the strategy for development to follow, which in turn is regarded to have been based on export pessimism. The reasoning can be disentangled as follows.

Prebisch (1950) and Singer (1950) considered the terms of trade of primary products relative to manufactures and concluded that these were declining, beyond the control of developing countries' policies. Factors in this decline were the relative low elasticities of demand for primary products, the increasing efficiency in their use as raw materials, and the invention and increased use of synthetic substitutes. Recently, Ardeni and Wright (1992) confirmed the declining terms of trade for primary products to be valid for the whole century up to 1988 and concluded that this trend cannot be explained away, as in cases of earlier studies, as a spurious regression phenomenon.

Since at the time, raw materials were the major export products of developing countries, Prebisch (1950) concluded that diversification of exports to include manufactures was necessary, if an ever widening gap between rich and poor nations was to be avoided. This in turn required the industrialization of the developing economies to some degree.

Of course, apart from export considerations, industrialization has long been regarded as an indispensable phase in economic development. The work of Kuznets (1971) and Lewis (1978) for instance indicates that economic development represented by rising productivity of labor in the economy as a whole, would require industrial activities and eventually services, absorbing labor from low productivity occupations in agriculture.

However, the followers of Prebisch believed that industrialization in the developing countries, in Latin America in particular, could only succeed by protecting the domestic infant industries. Prospects, furthermore, for manufactured exports were considered bleak. Nurkse (1959) believed that foreign markets would not be able to absorb growing manufactured exports from the developing countries. This pessimism was expressed again in Cline (1982). Bhagwati (1988) describes how this source of export pessimism was supplemented in the 1980 s by the argument that increasing manufactured exports from developing countries would find industrial countries' markets increasingly sealed off by protection.

On this basis, many developing countries relied on the domestic home market for the development of their industries, protecting these from foreign competition through high levels of barriers to imports. ${ }^{8}$

However, various other countries, especially in Asia, did not focus on import substitution exclusively but gave an important role to exports to stimulate their economic development. 


\subsection{Taxation and protection}

In developing countries the level of protection was shown in Table 3 to decrease with rising income per capita. A similar tendency can be shown to exist between income per capita and the share of taxes on trade in total government revenue. Table 4 shows that in low income countries with a per capita income up to $\$ 650$ in 1991, taxes on international trade had a share of almost 30 percent in government revenue, while for upper-middle income countries this figure was only 10 percent, decreasing further to nearly 2 percent in high income countries. ${ }^{9}$

In a recent review on taxation and development, Stern and Burgess (1993) arrived at the same conclusion. In addition it was found from different samples of developing countries that the openness of the economy (measured as the share of imports in GDP) was correlated positively with the share of import duties in GDP.

The World Bank (1988) analyzed taxation in developing countries and concluded that lack of trained administrative personnel is one of the factors preventing developing countries from applying broadly based income or consumption taxes. From this perspective, important differences are reported among the administrative costs for various types of taxes. For taxes on trade, such administrative costs are calculated to range from 1 to 3 percent of the revenue collected. The corresponding figures for Value Added Tax can be as high as 5 percent, for personal income taxes up to 10 percent.

Bliss (1992) explains further that the great advantage of tariffs from the point of view of administrative feasibility is that in many countries there are only a few ports through which traded goods can pass easily. This contrasts with the difficulties of collecting sales taxes, VAT, and income taxes.

Yet, the economic costs of trade taxes are higher than those of domestic taxes. Economic costs are defined here in terms of the social benefits and costs of resource allocation and changes therein, induced by taxes (World Bank 1988). In a case study on the Philippines, the marginal economic costs of raising revenue from domestic commodity taxes are close to zero, whereas for revenue from tariffs such costs are nearly half the revenue at a tariff of 10 percent-rapidly increasing to 2.25 times the revenue at a tariff rate of 25 percent.

Relative high economic costs of taxes on trade make increased dependence on other forms of taxation desirable, but relatively low costs of administration

Table 4. Taxes on international trade as a percentage of governmental revenue.

\begin{tabular}{lcrr}
\hline \multicolumn{1}{c}{ Country Group } & Income per Capita in US \$ in 1991 & 1980 & 1991 \\
\hline Low-income & $80-650$ & 28.6 & 29.6 \\
Lower-middle-income & $640-2.520$ & 27.6 & 22.8 \\
Upper-middle-income & $2.530-7.820$ & 13.4 & 10.1 \\
High-income & $11.120-33.610$ & 2.4 & 1.5 \\
\hline
\end{tabular}

Source: Computed from World Bank (1993, Table 12).

${ }^{a}$ Countries are included when data are available for 1980 and 1991 . Percentages represent unweighted averages over countries. 
prevent this. From this perspective, the IMF (1992) concludes that in countries that depend heavily on import taxes, a reform of the domestic tax system is required before tariffs can be brought down.

\subsection{Protecting the balance of payments}

Protection in developing countries being higher than in industrial countries reflects also the different roles that import border charges have in these two groups of countries. Of primary importance, according to UNCTAD (1990), is the role of import charges as a means to protect the balance of payments in developing countries. 10

The IMF (1992) indicates that in the context of inappropriate economic policies and appreciation of the real exchange rate, discretionary import licensing and foreign exchange restrictions are used to limit the demand for, and allocate the supply of, foreign exchange to cope with chronic balance and payments pressures. It is reported that some 80 percent of quantitative restrictions notified to GATT by developing countries were justified for balance of payments reasons under Article XVIII-B of the GATT.

More in particular, there is evidence (Whalley 1989), that many developing countries have imposed controls on external trade and finance in a cyclical way. ${ }^{11}$ In response to the first oil price increases in 1973 and to the subsequent recession, and to the debt crisis in the early 1980s, many formerly liberal developing countries tightened trade and exchange restrictions.

Anjaria (1987) analyzed in detail the scope and use of GATT Article XVIII-B enabling developing countries to apply quantitative trade restrictions on a temporary basis to protect their external financial position when facing a deterioration in the balance of payments. The Declaration on Trade Measures Taken for Balance of Payments Purposes adopted in 1979 at the end of the Tokyo Round broadened the scope of Article XVIII (and of Article XII) ${ }^{12}$ to include trade meaures other than quantitative restrictions, such as import surcharges and advance import deposits. Trade measures taken in view of balance of payments difficulties usually will have a general character, but article XVIII-B-10 allows variation in the restrictiveness of such measures depending on the "essentiality" for economic development of the products concerned.

Two important reasons have recently diminished the usefulness of trade restrictions to remedy balance of payments difficulties (Anjaria 1987). First, in a world of floating exchange rates and increased mobility of capital, the use of trade restrictions to improve the balance of payments may be ineffective or even counterproductive, as they may induce a compensating appreciation of the currency of the restricting country. Secondly, there is a growing awareness of the effectiveness of macroeconomic policy instruments, such as the exchange rate, to deal with balance of payments difficulties. 


\subsection{Preferential treatment and the GATT}

Since World War II, the industrial countries and the developing countries have gone different ways in handling their trade policies (Wolf 1987a). The industrial countries have engaged in a series of multilateral trade negotiations within the framework of GATT and, especially in Europe, they have successfully concluded agreements on trade liberalization and economic integration among subgroups of countries. As a result, trade policies among the industrial nations have tended to converge. Developing countries on the other hand, until recently, largely stood aside from the multilateral negotiations. As a consequence, trade policies have diverged from those in the industrial countries and also among the developing countries themselves. Because trade policies are not bound by the agreements of the GATT rounds, the developing countries have generally ended up with a high level of protection (see Table 3).

Yet, developing countries have not been totally absent from GATT activities. Even in the late 1940s several of them actively participated in the negotiations on the Havana charter, from which the GATT emerged. In 1955, Article XVIII of the GATT, dealing with government assistance to economic development, was revised. A balance of payments provision relating to developing countries was introduced and international surveillance over trade restrictions imposed by developing countries for balance of payments reasons was loosened. In particular, Article XVIII-B allows developing countries to impose quantitative import restrictions when facing balance of payments difficulties ${ }_{y}^{13}$ with Article XVIII-C incorporating the notion of infant industry protection (Anjaria 1987). De Paiva Abreu (1990) points out that the use of Article XVIII-B has been easy to the extent that developing countries recently resorted only rarely to the use of Article XVIII-C,14 with the consequence that protection in developing countries has become very high.

In 1966 part IV of the GATT was adopted. Entitled "Trade and Development," it obliges industrial GATT-member countries to extend special and differential treatment to developing countries. Nonreciprocity on the part of developing countries was accepted (Wolf 1987b).

Developing countries had participated in the Kennedy Round of trade negotiations (1964-1967) only marginally, but more actively in the Tokyo Round (1973-1979). The enabling clause was adopted, providing for more favorable treatment as an integral part of the GATT system, through such measures as (GATT 1979):

1. Tariff preferences under the Generalized System of Preferences (GSP)

2. Special treatment for the least developed countries

3. Strengthening the obligation for industrial countries to refrain from requesting concessions from developing countries that are incompatible with their needs

On the other hand, the clause also states the expectation that developing countries will gradually participate more fully in the GATT system of rights and obliga* tions as their economic development proceeds. The enabling clause represented 
a compromise between the developing countries' wish for their preferential status to be further legalized under GATT, and the industrial countries' desire that developing countries gradually assume responsibilities under GATT on an equal basis (Koekkoek 1988).

In the Uruguay Round of trade negotiations (1986-1993), the developing countries have played a far more prominent role than in the previous rounds. Of the 106 countries that started the negotiations, 76 were developing nations. ${ }^{15}$ Correspondingly, agriculture and textiles have been included in the final agreement. GATT (1993) provides an overview of the Final Act of the Uruguay Round, including the arrangements for special treatment of the developing countries.

Regarding market access for agricultural products, nontariff measures are to be replaced by tariffs, which in turn are to be reduced in time. For the industrial countries this reduction is 36 percent in six years, but for developing countries less, namely 24 percent in 10 years, while least developed countries are not required to reduce their tariffs. The same figures apply to developed and developing countries for the reduction in export subsidies below the level of the 1986-1990 base period. In general, a special decision sets out provisions for the negative effects from liberalization in agriculture on the least developed countries and on net food-importing developing countries.

Integration of textiles and clothing into GATT will be done in three stages covering a transition period of 10 years (1995-2005). The agreement focuses largely on phasing out the bilateral quotas negotiated under the Multifibre Arrangement (MFA). Again, the agreement has provisions for special treatment of the least developed countries.

Special conditions for developing countries, and in some cases for the least developed countries, are also included in the agreements on technical barriers to trade, on subsidies and countervailing measures, on safeguards, on trade in services, on trade related intellectual property rights, and on the settlement of disputes.

\section{Effects of protection}

\subsection{Resource allocation}

Protection against imports has the effect of encouraging firms to enter and produce for limited domestic markets, largely insulated from international competition. As a result, there is a tendency that these domestic firms operate in too many sectors, partly outside the country's comparative advantage, and, consequently, on an inefficiently small scale (Thomas and Nash 1991).

Measures for the effects of protection on resource allocation include the rate of effective protection, the domestic resource cost criterion, and the application of the true protection concept, to be taken up in the next two sections.

Associated with protection is a further loss in efficiency of resource allocation. Entrepreneurial activities are substituted for by seeking protection or its increase and extension, and by obtaining import licences. Such lobbying activities are 
usually not profitable from a societal point of view. These activities use up real resources but do not produce goods or services that enter a utility function of the society. For this reason Bhagwati (1982) analyzes such lobbying for increased protection under the heading: "Directly Unproductive Profit-Seeking Activities (DUP)." Earlier, Krueger (1974) used the expression: "rent-seeking activities."

Protection is likely to have a further effect on the distribution of income. Protecting production in economic sectors outside a country's comparative advantage increases demand for the production factors that are scarce relative to those that are abundantly available. This reasoning is reflected in the Stolper-Samuelson theorem which postulates that an increase in the relative price of a commodity raises the return of the factor used intensively in its production. Bourgignon and Morisson (1989) confirm for a sample of 37 developing countries that increasing protection is indeed associated with a decreasing share in total income of the poorer population groups, who provide predominantly labor.

Economies maintaining substantial protectionist restrictions become insulated from international price movements and other developments on the world market. Thomas and Nash (1991) observe that such economies gradually undermine their competitiveness, restrict export opportunities, and become very vulnerable to external shocks that cannot be fended off, leading in turn to serious macroeconomic imbalances.

Salvatore and Hatcher (1991) evaluated the effects of an outward orientation on, among others, the efficiency in resource use. To that end, 41 developing countries were classified according to four categories of openness on the basis of their trade policies in the period 1973-1983: outward oriented (strong or moderate) and inward oriented (strong or moderate). One of the findings is support for the thesis that industrialization under a strongly inward orientation leads to serious inefficiencies that neutralize the positive contribution that industrialization can potentially make to the growth of real per capita income and development.

\subsection{Effective protection and domestic resource costs}

Protection increases the opportunities for producing and selling import substitutes in a protected market. This in turn is likely to attract additional resources to these activities compared to the situation without protection.

The effective rate of protection (ERP) has been designed to trace such changes in resource allocation. The ERP is based on the notion that tariff protection raises the price of the product concerned but that this price increase itself provides an incomplete measure of the protection offered, for at least two reasons:16

1. Tariff protection on output should be weighed against tariffs on inputs. The former increases protection; the latter lowers it by increasing the costs of production.

2. Tariffs and prices are only indirect representations of resource allocation; value added does so directly. 
The ERP combines these two elements. The ERP is calculated as the ratio of value added in the case with protection and value added in the case of free trade. For sector $\mathrm{j}$ this is defined as:

$$
\mathrm{ERP}_{\mathrm{j}}=\left[\left(1+\mathrm{t}_{\mathrm{j}}\right)-\Sigma_{\mathrm{i}}\left(1+\mathrm{t}_{\mathrm{i}}\right) \mathrm{a}_{\mathrm{ij}}\right] /\left[1-\Sigma_{\mathrm{i}} \mathrm{a}_{\mathrm{ij}}\right]
$$

in which $a_{i j}$ represents the intermediate use of product $i$ in the production of $j$, and $t_{i}$ and $t_{j}$ are the corresponding tariff rates. The ERP $P_{j}$ therefore represents, per unit of output $\mathrm{j}$, the increase in total factor rewards due to protection relative to the situation of free trade.17

The ERP has been applied widely to evaluate trade policies in developing countries (Krueger 1984). Yet, the ERP may not represent additional resources per unit of output correctly to the extent that factor prices fail to reflect opportunity costs. Subsidies on capital and labor market imperfections are cases in point.

To remedy this the concept of domestic resource costs (DRC) has been developed, in which primary factors of production are valued at opportunity costs by the use of shadow prices. ${ }^{18}$ For measuring inefficiency in resource allocation, the superiority of the DRC criterion over the ERP is well established (Bhagwati 1978). Both the ERP and the DRC criteria are typically applied at the industry level in a partial equilibrium setting..$^{19}$ With substantial variation in outcome among industries, weighing problems arise in deriving conclusions on resource pulls in broader sectors (Greenaway and Milner 1987). To that end the concept of true protection has been developed, which in addition is set in a general equilibrium framework.

\subsection{True protection: the implicit tax on exports}

The concept of true protection defines the incidence of protection in terms of relative price changes in the three broad sectors of an economy (Sjaastad 1980):

1. Importables

2. Exportables

3. Nontradables 20

In the analysis it is assumed that importables and nontradables are substitutes to some degree both in production and consumption; this is also assumed for nontradables and exportables, but importables and exportables are supposedly nonsubstitutable. 21

Initially, the tariff raises the price of importables relative to both nontradables and exportables. Given a certain degree of substitution this shifts demand away from importables toward nontradables and shifts supply in the opposite direction. This in turn induces a price rise for nontradables, the extent of which depends on the degree of substitutability. Notwithstanding an assumed degree of substitutability between nontradables and exportables, the price rise of nontradables is not thought to trigger a similar process of shifts in demand and supply, leading 
to a higher internal price of exportables which is assumed to be constant (Clements and Sjaastad 1984; Greenaway and Milner 1987).

As a result, the import tariff leads to a price increase of importables relative to exportables and-probably to a lesser degree-to nontradables. The resulting price differential between importables and nontradables is probably less than the nominal tariff 22 and represents the true protection for the producers of import substitutes. From the perspective of producers of exportables, the resulting price differential represents a loss in purchasing power and indicates the burden of protection shifted to the export sector. In this way import protection is conceived to end up, at least partially, as an export tax.

The implicit tax of import protection on the export sector has three main sources (Clements and Sjaastad 1984):

1. The costs of imported inputs increases.

2. The protected sectors attract additional resources, raising their prices.

3. Declining imports result in less purchasing power for the trade partner, lowering their capacity to import in turn.

The true protection calculation framework not only allows the evaluation of import protection but also of export subsidies and of both at the same time. Both policies of import substitution and of export promotion are often applied simultaneously but not necessarily in a coordinated way. The concept of true protection provides a framework for a consistent evaluation of both policies and for evaluating their net effects.

Clements and Sjaastad (1984) have applied the true protection concept to evaluate the trade policies in the 1960s and 1970s of six developing countries in Latin America. They found that the proportion of import protection that is shifted in the form of an implicit export tax varies from 53 to 95 percent, with a mean value of the shift parameter of 67 percent. Greenaway and Milner (1987) estimated a shift parameter for Mauritius in the period 1976-1982 of 59 percent, and concluded from these results that the net effect of the trade policies investigated was a likely pull of resources into activities of import substitution and away from the export sector.

In a similar way, DeRosa (1991) investigated import-restricting policies and their effect on the export performance of 23 sub-Saharan countries. The levels of protection in sub-Saharan countries are substantially higher than in most other developing countries. The figures in Table 5 further indicate that the lowest income countries have the highest rates of protection, especially for nontariff barriers. DeRosa (1991) reports, furthermore, that sub-Saharan countries maintain escalating tariff rates and that protection is directed especially against labor-intensive products.

A multicommodity model of trade and exchange rate adjustment was used to measure the effects of trade liberalization on exports. Trade liberalization was represented by a reduction of import duties to a uniform rate of 10 percent and by a relaxation of the NTB impact on the volume of imports by 25 percent. ${ }^{23}$ The results are given in Table 5 and suggest an increase in export earnings of more than 30 percent per year for all 23 countries, representing 3.5 percent of their GDP, and of 
Table 5. Import restrictions and estimated effects on exports of trade liberalization in sub-Saharan countries, 1987.

\begin{tabular}{|c|c|c|c|c|c|c|c|}
\hline & \multicolumn{3}{|c|}{ Import Restrictions } & \multicolumn{4}{|c|}{ Effects of Trade Liberalization ${ }^{b}$} \\
\hline & \multirow{2}{*}{$\begin{array}{c}\text { Mean } \\
\text { Tariff } \\
\%\end{array}$} & \multirow{2}{*}{$\begin{array}{c}\text { Total } \\
\text { Charges } \\
\%\end{array}$} & \multirow{2}{*}{$\begin{array}{c}\text { All NTBs } \\
\text { Frequency } \\
\%\end{array}$} & \multirow{2}{*}{$\begin{array}{c}\text { Price } \\
\text { Change }^{c} \\
\%\end{array}$} & \multicolumn{3}{|c|}{ Volume in $\%$} \\
\hline & & & & & $\begin{array}{l}\text { Primary } \\
\text { Goods }\end{array}$ & $\begin{array}{l}\text { Manu- } \\
\text { factures }\end{array}$ & $\begin{array}{c}\text { All } \\
\text { Goods }\end{array}$ \\
\hline All countries ${ }^{\mathrm{a}}$ & 29 & 33 & 81 & 34 & 30 & 51 & 33 \\
\hline Low-income $e^{a}$ & 30 & 34 & 89 & 39 & 35 & 58 & 37 \\
\hline Middle-income $e^{a}$ & 22 & 30 & 48 & 15 & 11 & 23 & 12 \\
\hline
\end{tabular}

Source: DeRosa (1991).

a 23 sub-Saharan countries; income per capita of $\$ 500$ per annum is the borderline between low- and middle-income countries.

${ }^{b}$ Trade liberalization includes the reduction of import duties to a uniform rate of 10 percent and a reduction in NTB coverage of 25 percent.

${ }^{c}$ Price of exports relative to nontraded goods.

nearly 40 percent per annum for the exports of the low-income countries among them. DeRosa (1991) also concluded that simulated import liberalization promotes greater proportional expansion of nontraditional, manufactured exports than of traditional, primary exports.

DeRosa (1991) adds however that more robust export performance cannot be regained by reforming trade policies alone, but that other policy reforms are needed as well.

\subsection{Experience with trade liberalization}

The costs of protection have their opportunity value in the benefits from trade liberalization. From this perspective, the IMF (1992) observes that, since the mid-1980s, many developing countries have pursued structural reforms, including the liberalization of trade policies. However, progress has been uneven across the regions of the world. In Latin America, where a strong inward orientation prevailed up to 1985, the shift in the orientation of trade policies has been most striking. A rapid elimination of quantitative restrictions has been carried out, with subsequent reductions in tariffs to low and uniform levels. ${ }^{24}$ In contrast, in east and southeast Asia, where most countries had relatively open systems since the early 1980 s, reforms have tended to be gradual. Finally, many countries in Africa and south Asia have not yet opened their economies to foreign competition to a significant degree. The IMF (1992) observes that reforms are continuing and that more countries are likely to adopt open trade systems in the near future. A key feature of these latest reforms is that they are part of an integrated package of macroeconomic and structural reforms often supported by multilateral institutions.

A World Bank study edited by Michaely, Papageorgiou, and Choksi (1991) evaluated earlier experience with trade liberalization in the period 1950-1982 in 19 
developing countries. ${ }^{25}$ The experiences of the individual countries leads to some general conclusions. Liberalizing countries tend to be countries with a higher per capita income than the nonliberalizing ones. Michaely et al. (1991) conclude, furthermore, that political stability is an important condition for the long-term success of trade reform. In connection with this it was found that a period of six years was the watershed for liberalization policies very likely to be sustained.

Thomas, Martin, and Nash (1990) and Thomas and Nash (1991) report on trade policy reforms in the period 1979-1987 in 40 developing countries, supported by adjustment lending programs. They conclude that the implementation of trade policy reforms has been weaker than expected. Four sets of domestic factors constraining sustained reform were identified:

- Vested interests against reform (four countries)

- Administrative and institutional bottlenecks (three countries)

- Macroeconomic instability (five countries)

- Lags in the supply response to policy reforms (especially in low-income countries in Africa)

They also conclude that the sustainability of trade policy reforms is enhanced by:

- Compensatory measures dealing with short term transitional costs

- Internal public commitment to the liberalization policy and the announcement of and adherence to a timetable of reforms

- External commitment to maintain reforms, such as joining the GATT, which raises the costs of reversing the reforms

The IMF (1992) has monitored the most recent experiences with liberalization of trade policies in developing countries. The sample of 36 developing countries contains major countries in each geographic region with respect to GDP and represents about 40 percent of total developing countries' trade in 1985. The 36 countries are listed in Appendix 2.

The trade liberalization evaluated by the IMF (1992) covers:

- Decontrol, that is, the elimination of NTBs

- Policies that shift the trade regime toward neutrality, that is, a reduction in the bias of incentives toward the production of import substitutes. ${ }^{26}$

In terms of openness, of the 36 developing countries reviewed, the IMF (1992) distinguishes four types of trade regimes. The classification of the 36 countries according to these regimes, before and after the trade reforms, is summarized in Table 6.27 Before the reforms, 28 countries out of the total of 36 had a trade regime with tight or significant control; after the reform, 25 countries were open to relatively open.

The IMF (1992) underlines that compared with programs of trade reform undertaken in earlier periods, the present programs were more frequently designed and 
Table 6. Trade regimes in 36 developing countries.

\begin{tabular}{|c|c|c|c|c|}
\hline \multirow[b]{2}{*}{ Trade Regime } & \multirow{2}{*}{$\begin{array}{c}\text { Quantitative } \\
\text { Restrictions Coverage } \\
\text { in Percentages }\end{array}$} & \multirow{2}{*}{$\begin{array}{c}\text { Tariffs in } \\
\text { Percentages }\end{array}$} & \multicolumn{2}{|c|}{ Number of Countries } \\
\hline & & & Before Reform & After Reform \\
\hline Tight Control & $>50$ & no limit & 21 & 3 \\
\hline Significant Control & $15-50$ & no limit & 7 & 8 \\
\hline Relatively Open & $5-15$ & $>50$ & 7 & 16 \\
\hline Open & $<5$ & $<50$ & 1 & 9 \\
\hline Total & - & - & 36 & 36 \\
\hline
\end{tabular}

Source: IMF (1992).

${ }^{\text {a }}$ Coverage in percentages of total imports under restrictions (in most cases) or of total tariff code items (in the remaining cases).

${ }^{b}$ Tariffs and other import taxes in percentages of the price.

implemented in the context of comprehensive macroeconomic and structural adjustment programs. These introduced complementary measures to deregulate product and factor markets, to improve the efficiency of the public sector, to improve public spending and tax programs, and to attract foreign investment. These measures aim to improve the responsiveness of economic agents to changes in relative prices and in the climate for private sector investment. In turn, these measures also aim at reducing the costs of adjustments arising from trade policy reforms, for instance when formerly protected sectors become exposed to import competition.

In a longer time perspective however, the effects of trade policy reforms turn out to be very beneficial. Such evidence is not yet reported on the 36 developing countries reviewed, but in this respect the IMF (1992) draws on an earlier study of 41 developing countries (IMF 1990). These countries were classified according to four degrees of outward orientation and showed striking differences in performance in terms of economic growth and the contribution therein of total factor productivity. The results are summarized in Table 7.

\section{Summary and Conclusions}

In developing countries the trade-weighted average tariff is 21 percent, the unweighted frequency average of nontariff barriers (NTBs) is 62 percent. Both for primary products and for manufactures, average protection comes close to these figures for total trade. Within primary products protection on mining products is lower than on food products. Within manufactures protection is particularly high on clothing, footwear, furniture, and textiles. The UNCTAD therefore concludes that the level and structure of protection in developing countries present a barrier to the expansion of intradeveloping countries' trade.

Protection in developing countries has a clear tendency to decrease with the level of development. Furthermore, customs receipts in developing countries on average are nine times higher than in industrial countries; NTBs have a four times higher frequency. 
Table 7. Trade orientation and growth.

\begin{tabular}{|c|c|c|c|c|}
\hline & \multicolumn{4}{|c|}{ In Annual Percentages } \\
\hline & \multirow[b]{2}{*}{$\begin{array}{c}\text { Growth of } \\
\text { Potential GDP }\end{array}$} & \multicolumn{3}{|c|}{ Contribution of } \\
\hline & & Capital & Labor & $\begin{array}{l}\text { Total Factor } \\
\text { Productivity }\end{array}$ \\
\hline \multicolumn{5}{|c|}{ Strongly outward-oriented countries } \\
\hline $1975-82$ & 8.4 & 4.6 & 1.1 & 2.7 \\
\hline $1983-89$ & 7.7 & 3.3 & 0.7 & 3.7 \\
\hline \multicolumn{5}{|c|}{ Moderately outward-oriented countries } \\
\hline $1975-82$ & 4.6 & 2.8 & 1.3 & 0.5 \\
\hline $1983-89$ & 4.1 & 1.7 & 1.2 & 1.2 \\
\hline \multicolumn{5}{|c|}{ Moderately inward-oriented countries } \\
\hline $1975-82$ & 4.0 & 2.6 & 1.5 & -0.1 \\
\hline $1983-89$ & 2.7 & 1.4 & 1.5 & -0.2 \\
\hline \multicolumn{5}{|c|}{ Strongly inward-oriented countries } \\
\hline $1975-82$ & 2.3 & 1.6 & 1.6 & -0.9 \\
\hline $1983-89$ & 2.2 & 0.7 & 1.6 & -0.1 \\
\hline
\end{tabular}

Source: IMF (1990).

Note: All figures are unweighted averages. The classification of countries by trade orientation is based on World Bank World Development Report, 1987.

Both in developing countries and in industrial countries tariffs rise with the level of processing. As a consequence, the simultaneous reduction of the escalation of protection in both groups of countries would be a positive sum game.

Various explanations apply for the observed tendency of protection to decrease with rising income per capita within the group of developing countries as well as between the latter and the industrial countries. The share of trade taxes in total government revenue has a similar tendency to decrease with higher income per capita. Lack of trained administrative personnel is one of the factors preventing developing countries from applying broadly based income and consumption taxes. In countries that depend heavily on import taxes, a reform of the domestic tax system is therefore required before tariffs can be decreased.

Led by export pessimism, many developing countries relied on the domestic home market for the development of their industries, protecting these from foreign competition through high levels of barriers to imports. Protection in developing countries being higher than in industrial countries reflects also the role of import charges as a means of protecting the balance of payments in the former. In addition, GATT Article XVIII enables developing countries to apply quantitative trade restrictions on a temporary basis to protect their external financial position.

In general, the GATT in part IV obliges members to extend special and differential treatment to developing countries, and to accept nonreciprocity from them. Also, the final agreement of the Uruguay Round includes preferential treatment of developing countries in obligations to decrease protection.

Recently, many developing countries have joined the GATT. Previously, it was the industrial countries in particular that engaged in multilateral trade negotiations 
and concluded free trade agreements among themselves. As a result, trade policies in industrial countries converged, but diverged from those in developing countries; trade policies also diverged among developing countries.

Protection against imports has the effect of encouraging firms to enter and produce for a limited domestic market, largely insulated from international competition. Industrialization under a strongly inward orientation has been shown to lead to serious inefficiencies in resource allocation, which neutralize the positive contribution that industrialization can potentially make to economic development. A further loss in efficiency in resource allocation associated with protection is that entrepreneurial activities are substituted for by seeking new or additional protection against imports.

Import protection, furthermore, is a burden on the export sector, which cannot compensate in its price for increased costs of protected inputs. Evidence shows that trade liberalization at the import side can lead to a substantial rise in export performance.

Since the mid-1980s, many developing countries have pursued structural reforms, including the liberalization of trade policies. The gains from trade liberalization are the opportunity costs of protection. Evidence shows that liberalization of trade has important quantitative effects on economic growth and on factor productivity.

Recent programs of trade liberalization are designed and implemented more frequently than before within the context of macroeconomic and structural adjustment programs. The complementary measures aim to improve the responsiveness of economic agents to changes in relative prices and to reduce the costs of adjustments to trade liberalization, and for these reasons, aim at sustaining trade policy reforms to be sustained.

\section{Acknowledgments}

The author would like to thank Professor Dominick Salvatore for editorial advice. Assistance with references from Mr. C.J. van Opijnen of Erasmus University and Mr. P. Tsyba of UNCTAD is also gratefully acknowledged.

\section{Notes}

1. The coverage of countries and trade barriers is given in Appendix 1.

2. This finding is reported to be in contrast with the nature of NTMs applied by industrial countries, which would be more targeted to specific trade partner countries and to specific industries (Erzan et al. 1989).

3. Erzan et al. (1989) also point to some exceptions. In cases of products subject to licenses or quotas alone, average tariffs were not significantly higher than when such NTMs were not installed. In these cases balance of payment considerations may be the prime motivation for restricting imports.

4. For methodology, sensitivity, and qualifications, see Laird and Yeats (1990).

5. Tariff escalation in developed economies is reported, for example, in Balassa and Balassa (1984).

6. Tariff protection includes tariffs and other charges. From NTMs were excluded the general measures, that is, measures that are applied for all products; NTMs were represented by nonstach totals, that is, even when more than one NTM affects a product it is counted as only one. 
7. The criteria for the classification are listed in Appendix 2.

8. In this connection Erzan et al. (1989) found that the level of protection in developing countries increases with the size of the population, and thus with one aspect of market size.

9. UNCTAD (1990) observes that reliance on import taxes for government revenue is particularly strong in the least industrialized of the developing countries, where a wide range of imported goods is not produced locally and where, therefore, import taxes are often similar (in effect) to internal taxes in the developed industrial countries.

10. As a second factor UNCTAD (1990) mentions the role of import charges as a source of government revenue, which was taken up in Section 2.2 of this paper.

11. To absorb some of the fluctuations in export receipts, import bills and capital flows.

12. GATT Article XII also permits the use of quantitative restrictions for balance of payments difficulties, but with more intensive surveillance by GATT than that connected with Article XVIII-B, which was designed especially for developing countries.

13. See in particular Section 2.3 of this article.

14. When use of Article XVIII-C was made, however, the World Development Report (World Bank 1987) concluded that many developing countries protected their domestic industry well beyond the time needed to make infant industries competitive.

15. Finger and Olechowski (eds.) (1987). During the negotiations the number of participants has increased. Recent accessions of Fiji, Brunei, and Bahrain have brought the number of Uruguay Round participants to 117, among whom are four nonmember participants (GATT Focus, December 1993).

16. A third reason is of course that only tariff protection is considered; nontariff barriers are not incorporated. On the concept of tariff equivalents of nontariff barriers see Section 3.4.

17. For various reasons the ERP can be negative as well (Krueger 1984). The measure ERP, in (1) represents a simple case. Alternative and more complicated measures have been developed (see, e.g., Bulmer-Thomas 1982).

18. The DRC has different mathematical representations and economic interpretations, the discussion of which is outside the scope of this article (Bulmer-Thomas 1982).

19. Some exceptions are mentioned in Bulmer-Thomas (1982).

20. In empirical applications importables are represented by products actually imported under existing trade policies, exportables by products actually exported, and nontradables by those goods that natural and/or artificial protection prevents from being traded internationally (Clements and Sjaastad 1984).

21. These relations of substitutability are based on the assumption that in terms of relative factor contents, the nontradables have an intermediate position between exportables and importables (Greenaway and Milner 1987).

22. When nontradables and importables are perfect substitutes the price increase in both sectors will be the same in the end. Likewise, when exportables and nontradables are perfect substitutes, the price differential with importables will be the same in the end for both sectors.

23. A relaxation with 10 percent represents the other scenario reported in DeRosa (1991).

24. Quantitative Restrictions and, in general, NTBs are far more damaging than tariffs. NTBs fragment the market and block the forces of specialization in the market. Tariffs, on the other hand, increase the price but leave the signaling functioning of prices in tact and are therefore a market-conforming instrument of protection. In this sense is the tariff equivalence of NTBs a misleading concept.

25. This large World Bank project resulted in seven volumes, six of which contain the 19 country studies prepared by 32 authors. Michaely et al. (1991) is the seventh volume and presents an overview of the findings.

26. The concept of neutrality of incentives between the export sector and the sector producing import substitutes is explained in Bhagwati (1988).

27. The structure of trade policies after the reform in the 36 developing countries is represented in detail in Appendix 2. 


\section{Appendix 1: Trade control measures in developing countries}

The data on the extent of trade control measures in developing countries, as displayed in Tables 1 and 3 in the main text, are derived from the report by the UNCTAD secretariat: Trade Expansion among Developing Countries: Constraints and Measures to Overcome Them (UNCTAD, TD/B/1260, Geneva, 1990). The aggregate statistics for the developing countries as a group are derived from the data for individual developing countries in the Handbook of Trade Control Measures of Developing Countries, 1987 (UNCTAD/D/DMM/Misc. 2/GE.89-55071, Geneva, 1989.

\section{Country Coverage}

The Handbook (UNCTAD 1989) contains data on trade measures on the following developing countries: Algeria, Angola, Antigua and Barbuda, Argentina, Bahamas, Bahrain, Bangladesh, Barbados, Belize, Benin, Bolivia, Brazil, Burkina Faso, Burundi, Cameroon, Central African Republic, Chile, China, Colombia, Congo, Costa Rica, Côte d'Ivoire, Cuba, Cyprus, Dominica, Ecuador, Egypt, El Salvador, Ghana, Grenada, Guatemala, Guinea, Guyana, Haiti, Hong Kong, India, Indonesia, Iran (Islamic Republic of), Iraq, Jamaica, Jordan, Kenya, (Democratic People's Republic of) Korea, (Republic of) Korea, Kuwait, Libyan Arab Jamahiriya, Madagascar, Malawi, Malaysia, Mexico, Morocco, Mozambique, Nepal, Nicaragua, Nigeria, Oman, Pakistan, Papua New Guinea, Paraguay, Peru, Philippines, Qatar, Romania, Saint Kitts and Nevis, Saint Lucia, Saint Vincent and the Grenadines, Saudi Arabia, Senegal, Sierra Leone, Singapore, Somalia, Sri Lanka, Sudan, Syrian Arab Republic, (United Republic of) Tanzania, Thailand, Trinidad and Tobago, Tunisia, Turkey, Uganda, United Arab Emirates, Uruguay, Venezuela, Viet Nam, Yemen, Yugoslavia, Zaire, Zambia, Zimbabwe.

\section{Trade Control Measures}

The Handbook (UNCTAD 1989) reports for each of the developing countries on the extent of the following trade control measures:

1. Tariffs

2. Additional Charges

3. Nontariff measures

1. Tariffs include customs duties and fiscal duties. Preferential rates were discarded and the lowest of the remaining rates applied was taken as the tariff rate reported. Since data on imports at the tariff lines of the national classification are usually lacking, simple averages were used to arrive from tariffs at national tariff lines to mean tariff rates at each heading of the Customs Cooperation Council Nomenclature (CCCN). From there, import-weighted averages were used 
to arrive at tariff rates of product categories of the Standard International Trade Classification (SITC). Average tariffs for total trade and across countries again were import-weighted averages.

2. Additional charges include customs surcharges and surtaxes, stamp tax, certain other fiscal charges, and tax on foreign exchange transactions. Excluded are taxes such as sales tax, which are levied on imports and domestic production alike. Excluded are taxes on services actually rendered such as statistical tax and port tax. Certain other charges such as license fees and consular invoice fees are also excluded because of lack of consistent data. The average procedure is as with tariffs.

3. Nontariff measures (NTMs) include quantitative restrictions (QRs) in the form of

- Licenses: discretionary licenses, import authorizations, licenses for selected purchasers

- Quotas: global quotas

- Prohibitions: total prohibition, temporary prohibition, suspension of issuance of licenses

In addition, such measures as advance import deposits, foreign exchange restrictions, fixed customs valuations and state trading monopolies were also considered.

NTMs are expressed as frequency ratios. Unweighted frequency averages were used to arrive at NTM-coverage from the national tariff lines to the CCCN headings and from there to the SITC categories, to total imports, and to averages over countries. At the national tariff lines the frequency of NTM was taken as $0 \%$ if no NTM was applied at that tariff line, as 50\% if an NTM affected part of the products specified at that tariff line, and as $100 \%$ if all the products specified were affected by one or more NTM.

\section{Appendix 2: Current structure of developing country trade regimes}

The IMF (1992) reports on a review of the trade policy reforms in 36 major developing countries in each geographic region. This appendix classifies the 36 countries under four headings according to the characteristics of their trade policies after the reform.

Table A1.

\begin{tabular}{|c|c|c|c|c|c|}
\hline \multirow[b]{2}{*}{ Country } & \multirow{2}{*}{$\begin{array}{c}\text { Most } \\
\text { Recent } \\
\text { Year of } \\
\text { Reform }\end{array}$} & \multicolumn{2}{|c|}{ Tariffs and Surcharges ${ }^{1}$} & \multicolumn{2}{|c|}{ Quantitative Restrictions } \\
\hline & & $\begin{array}{l}\text { Statutory Tariff } \\
\text { (in percent) }\end{array}$ & $\begin{array}{l}\text { Charges } \\
\text { (in percent) }\end{array}$ & Main Measure & $\begin{array}{l}\text { Coverage }^{3} \\
\text { (in percent) }\end{array}$ \\
\hline \multicolumn{6}{|l|}{ Tight Control } \\
\hline India & 1990 & $0-295$ & $0-78$ & Nonautomatic licensing & 70 \\
\hline Nepal & 1989 & $5-100$ & $0-105$ & Nonautomatic licensing & $>50$ \\
\hline Tanzania & 1990 & $0-60$ & $0-50$ & FX allocation & $>50$ \\
\hline \multicolumn{6}{|c|}{ Significant Control } \\
\hline Bangladesh & 1990 & $0->100$ & & Prohibitions & $24^{4,5}$ \\
\hline Cameroon & 1991 & $0-100$ & $5-10$ & Nonautomatic licensing & $15-50$ \\
\hline Malawi & 1991 & $0-45$ & $0-85$ & Nonautomatic licensing & $17^{6}$ \\
\hline Morocco & 1989 & $0-45$ & $0-13$ & Nonautomatic licensing & $22^{4}$ \\
\hline Nigeria & 1989 & $0-200$ & 7 & Prohibitions & $21^{4}$ \\
\hline
\end{tabular}


Table A1. Continued.

\begin{tabular}{|c|c|c|c|c|c|}
\hline \multirow[b]{2}{*}{ Country } & \multirow{2}{*}{$\begin{array}{l}\text { Most } \\
\text { Recent } \\
\text { Year of } \\
\text { Reform }\end{array}$} & \multicolumn{2}{|c|}{ Tariffs and Surcharges 1} & \multicolumn{2}{|c|}{ Quantitative Restrictions } \\
\hline & & $\begin{array}{c}\text { Statutory Tariff } \\
\text { (in percent) }\end{array}$ & $\begin{array}{l}\text { Charges } \\
\text { (in percent) }\end{array}$ & Main Measure & $\begin{array}{r}\text { Coverage }^{3} \\
\text { (in percent) }\end{array}$ \\
\hline Pakistan & 1991 & $0-95$ & $0-15$ & Prohibitions & $21^{4,7}$ \\
\hline Tunisia & 1990 & $0-43$ & $15-30$ & Nonautomatic licensing & 30 \\
\hline Zambia & 1990 & $15-50$ & $0-20$ & FX allocation & $15-50$ \\
\hline \multicolumn{6}{|l|}{ Relatively Open } \\
\hline Brazil & 1991 & $0-65$ & & & $1^{4}$ \\
\hline Colombia & 1991 & $0-63$ & $0-16$ & & $14^{4}$ \\
\hline Côte d'Ivoire & 1987 & $5-30$ & $0-12$ & & $7^{4}$ \\
\hline Ecuador & 1991 & $5-35$ & $\ldots$ & & $15^{4}$ \\
\hline Indonesia & 1990 & $0-40$ & $0-40$ & & $15^{4}$ \\
\hline Jamaica & 1988 & $0-60$ & $\ldots$ & & 7 \\
\hline Kenya & 1991 & $0-100$ & $\ldots$ & & 6 \\
\hline Malaysia & 1989 & $\ldots$ & $\ldots$ & & 5 \\
\hline Peru & 1991 & $15-25$ & $\ldots$ & & 5 \\
\hline Philippines & 1989 & $10-50$ & $0-25$ & & $8^{4}$ \\
\hline Senegal & 1991 & $15-45$ & $10-50$ & & $6^{4}$ \\
\hline Sri Lanka & 1990 & $5-50$ & $\ldots$ & & $9^{4}$ \\
\hline Thailand & 1990 & $0-100$ & & & $8^{4,8}$ \\
\hline Trinidad and Tobago & 1991 & $5-45$ & $0-60$ & & $0^{9}$ \\
\hline Venezuela & 1991 & $0-20$ & $\ldots$ & & 10 \\
\hline Zaire & 1986 & $0-50$ & $0-23$ & & 8 \\
\hline \multicolumn{6}{|l|}{ Open } \\
\hline Argentina & 1991 & $0-22$ & $0-4$ & & $4^{4}$ \\
\hline Bolivia & 1988 & $5-10$ & $1-2$ & & 2 \\
\hline Chile & 1988 & $15^{10}$ & $5-20$ & & $\overline{0}$ \\
\hline Costa Rica & 1990 & $1-40$ & $0-18$ & & 1 \\
\hline Gambia, The & 1991 & $0-23$ & $\ldots$ & & 1 \\
\hline Ghana & 1988 & $0-25$ & $0-23$ & & 0 \\
\hline Korea & 1990 & $1-50$ & & & 4 \\
\hline Mexico & 1988 & $0-20$ & & & 2 \\
\hline Uruguay & 1985 & $0-45$ & $0-5$ & & 0 \\
\hline
\end{tabular}

Sources: International Monetary Fund, Annual Report on Exchange Arrangements and Exchange Restrictions; United Nations Conference on Trade and Development; General Agreement on Tariffs and Trade.

Notes:

$\mathrm{FX}=$ foreign exchange. Countries are classified based on the following criteria. In regimes with tight and significant control, quantitative restrictions (QRs) cover more than 50 percent or between 15 percent and 50 percent of imports, respectively. Relatively open regimes have QRs covering 5-15 percent of imports of QRs covering less than 5 percent of imports and maximum tariffs and charges that exceed 50 percent. An open regime has tariffs and other import taxes not greater than 50 percent and QRs covering less than 5 percent of imports. No allowance has been made for differences in the administration of QRs or the structure of tariffs, which may also affect the degree of restrictiveness of the trade system.

${ }^{1}$ When available, a range of tariffs is used. If not available, the unweighted average of statutory rates or an average effective rate was used. Very high rates applied to only one or two items have been excluded. Charges that were applied equally to domestic and imported goods have also been excluded.

${ }^{2}$ Quantitative restrictions include value limitations on imports through foreign exchange allocation or through the requirement that importers provide their own foreign exchange.

${ }^{3}$ Percent of total imports covered by all quantitative restrictions unless otherwise specified.

${ }^{4}$ In percent of total tariff code items.

5 Includes right-of-refusal items.

${ }^{6}$ Includes foreign exchange licensing and prior approval lists.

7 The restricted list covers 283 tariff lines and the banned list covers 818 items out of a total of 5,355 . Reductions were undertaken in both categories after April 1991.

${ }^{8}$ Refers to 1989.

${ }^{9}$ Target, end of 1991.

${ }^{10}$ Uniform tariff. 


\section{References}

Anjaria, S.J. (1987) "Balance of Payments and Related Issues in the Uruguay Round of Trade Negotiations," The World Bank Economic Review 1, 669-688.

Ardeni, P.G. and B. Wright (1992) "The Prebisch-Singer Hypothesis: A Reappraisal Independent of Stationary Hypotheses," The Economic Journal 102, 803-812.

Balassa, Bella and Carol Balassa (1984) "Industrial Protection in the Developed Countries," The World Economy 7, 179-196.

Bhagwati, J. (1978) Anatomy and Consequences of Exchange Controls Regimes. Cambridge, MA: Ballinger.

Bhagwati, J. (1982) "Directly Unproductive Profit-seeking (DUP) Activities," Journal of Political Economy 90, 988-1002.

Bhagwati, J. (1988) "Export-Promoting Trade Strategy: Issues and Evidence," The World Bank Research Observer 3, 27-57.

Bliss, Christopher (1992) "The Design of Fiscal Reforms in Revenue Constrained Developing Countries," The Economic Journal 102, 940-951.

Bourgignon, F. and C. Morrisson (1989) External Trade and Income Distribution, OECD Development Center Studies, Paris.

Bulmer-Thomas, V. (1982) Input-Output Analysis in Developing Countries, Chichester, : John Wiley \& Sons.

Clements, K.W. and L.A. Sjaastad (1984) "How Protection Taxes Exporters," Thames Essay No. 39, Trade Policy Research Center, London.

Cline, W. (1982) "Can the East Asian Model of Development be Generalized?" World Development $10,81-90$.

DeRosa, Dean (1991), "Protection in Sub-Saharan Africa Hinders Exports," Finance \& Development September, 42-45.

Erzan, R., H. Kuwahara, S. Marchese, and R. Vossenaar (1989) The Profile of Protection in Developing Countries. UNCTAD, Discussion Paper No. 21,

Finger, J.M. and S. Laird (1987) "Protection in Developed and Developing Countries-An Overview," Journal of World Trade Law 21, 9-23.

Finger, J.M. and A. Olechowski (eds) (1987) The Uruguay Round, A Handbook on the Multilateral Trade Negotiations. Washington DC: World Bank.

GATT (1993) "The Final Act of the Uruguay Round: A Summary." Focus, GATT, December, Geneva.

Greenaway, D. and C. Milner (1987) "True Protection Concepts and Their Role in Evaluating Trade Policies in LCDs," Journal of Development Studies 23, 200-219.

Greenaway, D. and C. Milner (1991) "Fiscal Dependence on Trade Taxes and Trade Policy Reform," The Journal of Development Studies 27, 95-132.

IMF (1990) World Economic Outlook October 1990. Washington, DC: International Monetary Fund.

IMF (1992) Issues and Developments in International Trade Policy. Washington DC: International Monetary Fund.

Koekkoek, K.A. (1988) "The Integration of Developing Countries in the GATT System," World Development 16, 947-957.

Krueger, A.O. (1974) "The Political Economy of the Rent-Seeking Society;" American Economic Review 64, 291-303.

Krueger, Anne O. (1984) 'Trade Policies in Developing Countries.' In R.W. Jones and P.B. Kenen (eds), Handbook of International Economics, Vol. I. Amsterdam: Elsevier Science Publishers. pp. 519-569.

Kuznets, S. (1971) Economic Growth of Nations. Cambridge, MA: Harvard University Press.

Laird, S. and A.J. Yeats (1990) "Empirical Evidence Concerning the Magnitude and Effects of Developing Country Tariff Escalation." In H. Singer, N. Hatti, and R. Tandon (eds), Trade Liberation in the 1990s. New Delhi: Indus Publishing Company, pp. 261-294.

Lewis, W.A. (1978) The Evolution of the International Economic Order. Princeton, NJ: Princeton University Press. 
Michaely, M., D. Papageorgiou, and A.M. Choksi (1991) Lessons of Experience in the Developing World, Liberalizing Foreign Trade, Vol. 7. Cambridge, MA: Basil Blackwell.

Nurkse, R. (1959) Patterns of Trade and Development. Wicksell Lectures, Stockholm: Almquist and Wicksell.

Paiva Abreu, M. de (1990) 'Developing Countries and the Uruguay Round of Trade Negotiations." Proceedings of the World Bank Annual Conference on Development Economics 1989 Washington DC: World Bank, pp. 21-46.

Prebisch, R. (1950) The Economic Development of Latin America and its Principal Problems. New York: United Nations.

Salvatore, D. and Th. Hatcher (1991) "Inward Oriented and Outward Oriented Trade Strategies." Journal of Development Studies 27, 7-25.

Singer, H.W. (1950) "The Distribution of Gains Between Investing and Borrowing Countries," American Economic Review 40, 473-485.

Sjaastad, L.A. (1980) "Commercial Policy, True Tariffs and Relative Prices," In John Black and Brian Hindley (eds), Current issues in Commercial Policy and Diplomacy. London: Macmillan.

Stern, N. and R. Burgess (1993) "Taxation and Development," Journal of Economic Literature 21, 762-830.

Thomas, V., K. Martin, and J. Nash (1990) Lessons in Trade Policy Reform, Policy and Research Series No. 10. Washington DC: The World Bank.

Thomas, V. and J. Nash (1991) "Reform of Trade Policy: Recent Evidence from Theory and Practice," The World Bank Research Observer 6, 219-240.

UNCTAD (1989) Handbook of Trade Control Measures of Developing Countries, DMM/Misc. 2/GE-89-550.71, Geneva: UNCTAD.

UNCTAD (1990) Trade Expansion Among Developing Countries: Constraints and Measures to Overcome Them, TD/B/1260. Geneva: UNCTAD.

Whalley, J. (1989) Recent Trade Liberalization in the Developing World, NBER Working Paper No. 3057. Wolf, Martin (1987a) "Why Trade Liberalization is a Good Idea," In Finger and Olechowski (eds), The Uruguay Round, A Handbook on the Multilateral Trade Negotiations. Washington DC: World Bank, pp. 14-21.

Wolf, Martin (1987b) "Differential and More Favourable Treatment of Developing Countries and the International Trading System," World Bank Economic Review 1, 647-668.

World Bank, The (1987), World Development Report 1987, Washington, D.C.: The World Bank.

World Bank, The (1988) World Development Report 1988. Washington DC: The World Bank. 